\title{
STRUCTURE AND PROPERTIES OF Ni22Cr10AI1Y COATINGS DEPOSITED BY THE VACUUM PLASMA SPRAY PROCESS
}

\author{
Mihailo R. Mrdak \\ Research and Development Center IMTEL Communications a.d., \\ Belgrade, Republic of Serbia, \\ e-mail: drmrdakmihailo@gmail.com, \\ ORCID iD: (i)http://orcid.org/0000-0003-3983-1605
}

https://dx.doi.org/10.5937/vojtehg65-11904

FIELD: Chemical Technology

ARTICLE TYPE: Original Scientific Paper ARTICLE LANGUAGE: English

\section{Summary:}

In this study, the aim was to deposit layers of the Ni22Cr10Al1Y coating using the vacuum plasma spray process to protect gas turbine engine components from oxidation and high-temperature corrosion. The coating can significantly affect the properties of the substrate because it forms a composite together with the substrate. The type of the coating deposition process and coating heat treatment, together with the substrate, significantly affect its resistance to high temperature creep. Ni22Cr10Al1Y powder was deposited with a vacuum plasma spray system of the Plasma Technik - AG company using the control panel A-2000 and the plasma gun F4. The coating deposited on the substrate of INCONEL X-750 alloy was thermally treated at $1100^{\circ} \mathrm{C}$ for 2 hours in a protective atmosphere of argon. The particle morphology was tested by scanning electron microscopy. The microhardness of layers was tested by the $H V_{0.3}$ method and the bond strength was tensile tested, in accordance with the standard Pratt \& Whitney. The microstructure of the deposited coating layers was examined under a light microscope. Coating etching was done by mixing $2.5 \mathrm{ml}$ of nitric acid $\mathrm{HNO}_{3}$ with $7.5 \mathrm{ml}$ of hydrofluoric acid $\mathrm{HF}$. The microstructure of the etched coating before and after heat treatment, as well as the thickness of the diffusion zone, were analysed under a light microscope, based on which the coating quality was later assessed.

Keywords: vacuum, substrates, structural properties, plasmas, layers, coatings.

ACKNOWLEDGEMENT: The author is thankful for the financial support from the Ministry of Education and Science of the Republic of Serbia (national project TR 34016). 


\section{Introduction}

The components of hot sections, such as gas turbine blades, have to withstand various stresses and severe environmental conditions at the operating temperatures of $900^{\circ} \mathrm{C}$ to $1000^{\circ} \mathrm{C}$. The structures of alloys for producing hot sections are developed with optimum mechanical properties and MCrAIY coatings to provide the resistance of hot sections to hightemperature oxidation and hot corrosion (Mrdak, 2016, pp.1-25). In recent years, MCrAIY alloys have been widely used while vacuum plasma spraying (VPS) is the leading process used for depositing coatings on hot sections such as blades which are exposed to aggressive gases at high temperatures. MCrAlY coatings have been extensively studied in recent years; they have shown good properties and adequate oxidation resistance to hot corrosion (Wang, et al, 2002, p.70), (Mrdak, et al, 2015, pp.337343). There are two basic systems of coatings used on gas turbines to improve the resistance to hot corrosion and high-temperature oxidation, in order to prolong the working life of components. These are diffusion coatings and diffusion coatings coated with ceramic coatings. The $\mathrm{Ni22Cr10Al1Y} \mathrm{coating} \mathrm{is} \mathrm{used} \mathrm{on} \mathrm{components} \mathrm{such} \mathrm{as} \mathrm{blades} \mathrm{and} \mathrm{other}$ gas turbine parts as the protection against hot corrosion and hightemperature oxidation up to $1100^{\circ} \mathrm{C}$ (Material Product Data Sheet, 2012, Nickel Chromium Aluminum Yttrium (NiCrAlY) Thermal Spray Powders, Amdry 9624, DSMTS-0102.0, Sulzer Metco). The chemical composition of the Ni22Cr10Al1Y coating should be compatible with the substrate material to reduce inter-diffusion during operation. Aluminum is an element which protects $\mathrm{Ni}$ alloys from oxidation up to $1200^{\circ} \mathrm{C}$ by forming oxide phases $\alpha-\mathrm{Al}_{2} \mathrm{O}_{3}$ on the coating surface. The microstructure of vacuum plasma sprayed Ni22Cr10Al1Y coatings consists of the $\mathrm{Y}-\mathrm{Ni}$ and $\beta-(\mathrm{NiAl})$ phases (Feuerstein, et al, 2008, pp.199-213), (Padture, et al, 2002, pp.280-284). In the microstructure, there are also present $\gamma^{\prime}-\left(\mathrm{Ni}_{3} \mathrm{Al}\right)$ precipitates in $\mathrm{Y}-\mathrm{Ni}(\mathrm{Cr})$ grains (Ma, et al, 2010, pp.1518-1529). The $\mathrm{Y}^{\prime}-\left(\mathrm{Ni}_{3} \mathrm{Al}\right)$ precipitates in the M22Cr10Al1Y alloy provide better mechanical properties at temperatures below the solvus temperature, which is typically between 800 and $980^{\circ} \mathrm{C}$ (Achar, et al, 2004, pp.272-283), (Ma, et al, 2010, pp.1518-1529), (Mendis, Hemker, 2008, pp.255-258). The phases existing in the coating in the etched condition differ by color. The light gray regions in the coating microstructure are $\mathrm{Y}-\mathrm{Ni}(\mathrm{Cr})$ grains which contain $\mathrm{Y}^{\prime}$ $\mathrm{Ni}_{3} \mathrm{Al}$ precipitates, and the $\beta$-NiAl phase is dark gray. The differences in the microstructure between the APS and the VPS coatings are caused by higher temperatures of vacuum plasma spraying which increase the cohesive strength of lamellae and reduce the amount of oxygen in the environment, 
thereby preventing oxidation of molten particles. In the coating layers, there are no oxides of the types: $\alpha-\mathrm{Al}_{2} \mathrm{O}_{3}, \mathrm{Cr}_{2} \mathrm{O}_{3}, \mathrm{NiO}$ and $\mathrm{NiCr}_{2} \mathrm{O}_{4}$, which occur in coatings deposited by the APS process (Mrdak, 2012, pp.182-201), (Mrdak, 2013, pp.26-47). When MCrAlY coatings are applied, it is known that there is an interaction between MCrAlY coatings with the substrate, which is negligible during the thermal spraying in comparison with coatings in exploitation. The thermal stability of sprayed coatings is decreased with increasing the working temperature of the gas turbine. The inter-diffusion degradation becomes important with the temperature increase. The interaction between the coating and the substrate of superalloys was tested by the author (Gómez-Acebo, et al, 2004, pp.237-251), (Dahl, et al, 2006, pp.pp.73-78), (Yuan, et al, 2014, pp.63-69), (Liu, et al, 2015, pp.63-69). The coating diffusion provides enrichment of the substrate surface with aluminum and chromium and a higher tensile bond strength. After the VPS deposition of MCrAlY coatings, thermal treatment is applied. The aim of the thermal treatment of the deposited coating with the substrate is to strengthen the coating by thermal precipitation of fine intermetallic $\gamma^{\prime}-\mathrm{Ni}_{3} \mathrm{Al}$ compounds in the grains of solid $\gamma-\mathrm{Ni}(\mathrm{Cr})$ solution and the grains of the $\beta$ $\mathrm{NiAl}$ phase which increase the resistance of the coating to hightemperature creep together with the substrate. Due to diffusion bonding, the tensile bond strength of the coating significantly increases. The diffusion coating-substrate bonding occurs in the temperature range of 900 $1150^{\circ} \mathrm{C}$. Examinations have shown that the microstructure of the MCrAlY coating thermally processed at $1000^{\circ} \mathrm{C}$ for 1 hour and then cooled with argon to the room temperature for 15 min consists of a $\gamma$ - solid solution rich in $\mathrm{Ni}$, Co and $\mathrm{Cr}$, which contains the dispersed phases of $\beta-\mathrm{NiAl}$ and $\gamma^{\prime}-$ $(\mathrm{Ni}, \mathrm{Cr})_{3}$ (Funk, et al, 2011, pp.2233-2241), (Tang, et al, 2006, pp.94-106). In case of the Ni22Cr10Al1Y coating, vacuum deposited on the substrate of the 1N738LC nickel alloy, and after thermal processing in vacuum at a temperature of $1100^{\circ} \mathrm{C}$ for 2 hours, its microstructure shows the presence of fine globular particles of the $\beta$-NiAl phase (dark gray) and uniformly distributed in the matrix of $\mathrm{y}-\mathrm{Ni}(\mathrm{Cr})+\mathrm{Y}^{\prime}-\mathrm{Ni}_{3} \mathrm{Al}$ which is light gray (Funk, et al, 2011, pp.2233-2241). Due to the diffusion of Al and Cr from the coating in the substrate, the coating/substrate interface shows a diffusion zone consisting of the light gray $\mathrm{Y}-\mathrm{Ni}(\mathrm{Cr})$ matrix that contains $\mathrm{Y}^{\prime}-\mathrm{Ni}_{3} \mathrm{Al}$ precipitates of the deposited $\beta$-NiAl compounds (in black). Because of the diffusion of chemical elements from the substrate, the lower layers of the coating contain the elements $\mathrm{Ni}$ and $\mathrm{Ti}$ which build fine $\mathrm{Y}^{\prime}-\mathrm{Ni}_{3}(\mathrm{Al}, \mathrm{Ti})$ precipitates with aluminum (Itoh, Tamura, 1999, pp.476-483), (Gómez-Acebo, et al, 2004, pp.237-251), (Dahl, et al, 2006, pp.73-78). 
The aim of this study was depositing a vacuum plasma sprayed (VPS) coating of the Ni22Cr10Al1Y alloy for the protection of gas turbine engine components against high-temperature corrosion and oxidation. In order to increase the resistance of the coating to high-temperature creep together with the substrate, thermal treatment was performed at $1100^{\circ} \mathrm{C}$ for 2 hours in a protective atmosphere of argon. The aim was to thermally deposit fine precipitates of $\mathrm{Y}^{\prime}-\mathrm{Ni}_{3} \mathrm{Al}$ (which strengthen the coating) into the grains of the solid solution $\mathrm{y}-\mathrm{Ni}(\mathrm{Cr})$ and the grains of the $\beta-\mathrm{NiAl}$ phase. After the thermal treatment, the mechanical properties of the coatings in the deposited condition were analyzed as well as the microstructure of the layers of the coatings in the deposited condition. The coating quality was assessed afterwards.

\section{Materials and experimental details}

Coatings were produced from AMDRY 9624 powder which protects the substrate from high temperature oxidation and hot corrosion at temperatures $\mathrm{t} \leq 1050^{\circ} \mathrm{C}$ (Material Product Data Sheet, 2012, Nickel Chromium Aluminum Yttrium (NiCrAlY) Thermal Spray Powders, Amdry 9624, DSMTS-0102.0, Sulzer Metco).

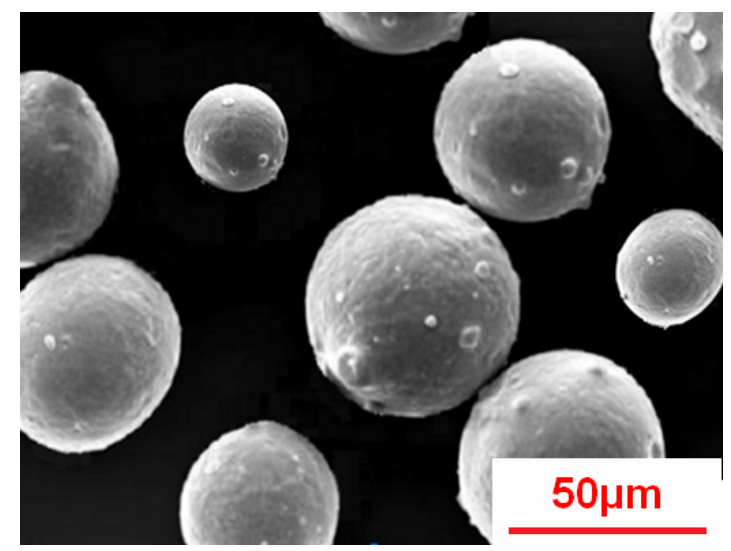

Figure 1 - (SEM) Scanning electron micrography of Ni22Cr10Al1Y powder particles

Puc. 1 - (SEM) Электронная микрографияя частиц порошка Ni22Cr10Al1Y

Слика 1 - (SEM) Скенинг електронска микрографија честица праха Ni22Cr10Al1Y

NiCrAlY powder is a nickel alloy with 22wt.\%Cr, 10wt.\%Al and $1 \mathrm{wt} . \% \mathrm{Y}$ with a range of powder particle granulation of $11-37 \mu \mathrm{m}$. For the powder production, the vacuum furnace melting technique was used as 
well as gas atomization of liquid melt with inert argon gas. The produced powder particles are homogeneous and spherical, Figure 1.

For microhardness testing and evaluation of the coating microstructure, the base was made of steel (X15Cr13 EN10027), thermally unprocessed, with the dimensions: $70 \times 20 \times 1.5 \mathrm{~mm}$. For testing the coating bond strength, the base was made of the same steel with the dimensions: $\varnothing 25 \times 50 \mathrm{~mm}$ (Turbojet Engine - Standard Practices Manual PN 582005, 2002, Pratt \& Whitney, East Hartford, USA). For testing the coating microstructure after heat treatment, the samples were made of an INCONEL X-750 alloy with the dimensions: 20x10x5 mm.

The mechanical properties of the layers were examined using the microhardness method $\mathrm{HV}_{0.3}$ and their bond strength was examined with tensile testing (Turbojet Engine - Standard Practices Manual PN 582005, 2002, Pratt \& Whitney, East Hartford, USA). The morphology of powder particles was examined by the SEM method. The microstructure of the coating layers in the deposited state and after heat treatment in the etched state was tested with light microscopy. The coating etching was done by mixing $2.5 \mathrm{ml}$ of nitric acid $\mathrm{HNO}_{3}$ with $7.5 \mathrm{ml}$ of hydrofluoric acid $\mathrm{HF}$.

Ni22Cr10Al1Y powder was deposited at low pressure with a vacuum plasma spray system of the Plasma Technik AG company. The control panel A-2000 and the plasma gun F4 were used for the powder deposition. Powder deposition was done with a mixture of plasma gases $\mathrm{Ar} / \mathrm{H}_{2}$. Before powder deposition, the surface of the INCONEL X-750 alloy substrate was cleaned and pre-heated with a transferred arc at a temperature of $850^{\circ} \mathrm{C}$. Table 1 presents the VPS parameters for cleaning the substrate surface and depositing Ni22Cr10Al1Y powder. The thickness of the coating deposited on the substrates ranged from 150-200 $\mu \mathrm{m}$. The coating deposited on the substrate of INCONEL Alloy X-750 was thermally treated at $1100^{\circ} \mathrm{C}$ in a protective atmosphere of argon for 2 hours.

Table 1 - Vacuum plasma spray parameters

Таблица 1 - Параметры ваккумного плазменного напыления Табела 1 - Вакуум-плазма-спреј параметри

\begin{tabular}{|l|l|l|}
\hline \multirow{2}{*}{ Parameters } & \multicolumn{2}{c|}{ Values } \\
\cline { 2 - 3 } & Cleaning arc & Spraying \\
\hline Plasma current, I $(\mathrm{A})$ & 500 & 700 \\
\hline Plasma Voltage, $\mathrm{V}(\mathrm{V})$ & 65 & 58 \\
\hline Primary plasma gas flow rate $\mathrm{Ar}(\mathrm{l} / \mathrm{min})$ & 50 & 50 \\
\hline Secondary plasma gas flow rate $\mathrm{He}^{(1)}, \mathrm{H}_{2}^{(2)}(\mathrm{l} / \mathrm{min})$ & $10^{(1)}$ & $8^{(2)}$ \\
\hline Carrier gas flow rate $(\mathrm{l} / \mathrm{min})$ & -- & 3 \\
\hline Powder feed rate $(\mathrm{g} / \mathrm{min})$ & -- & 40 \\
\hline
\end{tabular}




\begin{tabular}{|l|l|l|}
\hline \multirow{2}{*}{ Parameters } & \multicolumn{2}{c|}{ Values } \\
\cline { 2 - 3 } & Cleaning arc & Spraying \\
\hline Stand-off distance $(\mathrm{mm})$ & 270 & 270 \\
\hline Chamber pressure $(\mathrm{mbar})$ & 25 & 150 \\
\hline Nozzle diameter $(\mathrm{m} \mathrm{m})$ & 8 & 8 \\
\hline Speed of the gun $(\mathrm{mm} / \mathrm{s})$ & 20 & 250 \\
\hline
\end{tabular}

\section{Results and discussion}

The mean value of the microhardness of Ni22Cr10Al1Y layers was $198 \mathrm{HV}_{0.3}$. The lower value of the microhardness of the VPS Ni22Cr10Al1Y coating compared to the APS coating is caused by the absence of oxygen in the vacuum chamber, which prevents oxidation of molten particles in the deposition process. Low microhardness values confirm that in the coating deposited at low pressure there are not present $\alpha-\mathrm{Al}_{2} \mathrm{O}_{3}, \mathrm{Cr}_{2} \mathrm{O}_{3}, \mathrm{NiO}$ and $\mathrm{NiCr}_{2} \mathrm{O}_{4}$ oxides which increase the value of the microhardness of coatings deposited at atmospheric pressure (Mrdak, 2012, pp.182-201). Besides the absence of oxidation in vacuum, low pressure of Ar inert gas allows preheating of the substrate up to $850^{\circ} \mathrm{C}$, which leads to a substantial increase in adhesive bond strength. Tests have shown that the VPS-Ni22Cr10Al1Y coating has a bond strength of 84 $\mathrm{MPa}$. Preheating the substrate and a low pressure of inert gas in the vacuum chamber further increase the coating density by eliminating micro pores and unmelted particles, as confirmed by the analysis of the coating microstructure on the light microscope. It is known that oxides and micro pores on the lamellae boundaries weaken the inter-lamellar bond, ie. cohesive strength and adhesion strength of the coating bond. Tensile strength testing has established that the failure mechanism was purely adhesion at the substrate / coating interface.

Figure 2 shows the microstructure of the VPS-Ni22Cr10Al1Y coating. The qualitative analysis showed that the substrate/ coating interface cannot be noticed because of cleaning and pre-heating the substrate surface with a transferred arc. The substrate/coating interface does not show defects such as: discontinuity of deposited layers, micro and macro cracks, micro and macro pores and separation of the coating from the base. The coating is dense and in the coating layers there are no: oxide lamellae, micro pores, precipitates, and unmelted particles. To see the microstructure of the coatings in the deposited state, Figure 3 shows a photomicrograph of the coating in the etched state. In the VPS Ni22Cr10Al1Y coating, 
oxides and micro-cracks are completely suppressed, which resulted in an even and uniform deposition of layers.

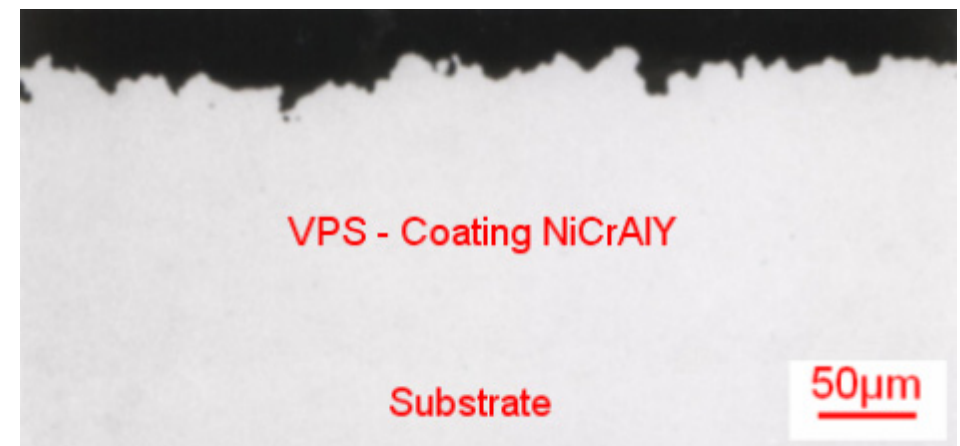

Figure 2 - (OM) micrograph of the vacuum plasma sprayed Ni22Cr10Al1Y coating Puc. 2 - (ОМ) микрография вакуумного плазменного напыления Ni22Cr10Al1Y Слика 2 - (ОМ) Микрографија вакуум-плазма напрскане превлаке Ni22Cr10Al1Y

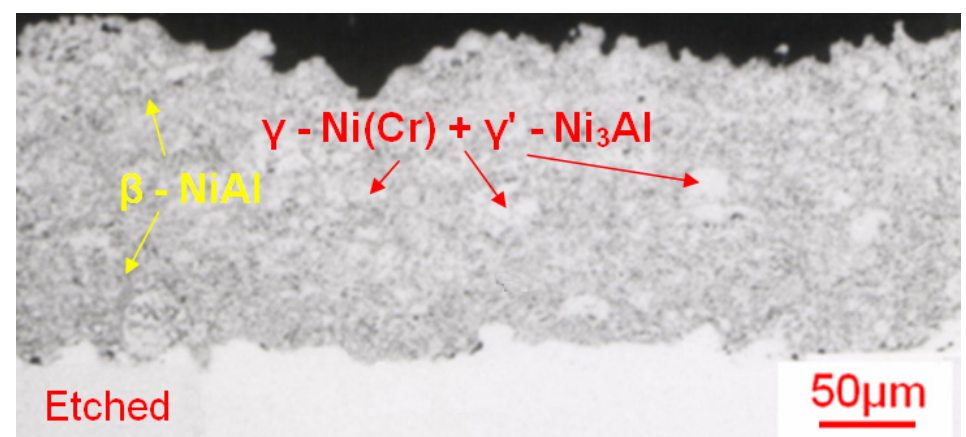

Figure 3-(OM) Etched microstructure of the vacuum plasma sprayed Ni22Cr10Al1Y coating

Puc. 3 - (ОМ) Поврежденная микроструктура покрытия, нанесенного вакуумным плазменным напылением Ni22Cr10Al1Y

Слика 3 - (ОМ) Нагризена микроструктура вакуум-плазма напрскане превлаке Ni22Cr10Al1Y

Due to high temperature of the substrate and a complete melting of the layer deposited with the previously deposited layer, the lamellar microstructure in the coating completely disappeared. Coating etching makes two phases recognizable in the microstructure, one of which is light gray and the other is dark gray. The main phase of the coating (light gray) is the solid solution $\mathrm{Y}-\mathrm{Ni}(\mathrm{Cr})$, which provides coating ductility and contains fine $\mathrm{Y}^{\prime}-$ $\mathrm{Ni}_{3} \mathrm{Al}$ precipitates while the dark gray $\beta-\mathrm{NiAl}$ phase provides resistance to oxidation (Funk, et al, 2011, pp.2233-2241). The coating microstructure 
shows more regular melting of powder particles in vacuum relative to the atmospheric pressure.

Figure 4 shows a photomicrograph of a largely magnified coating to see the coating microstructure more clearly.

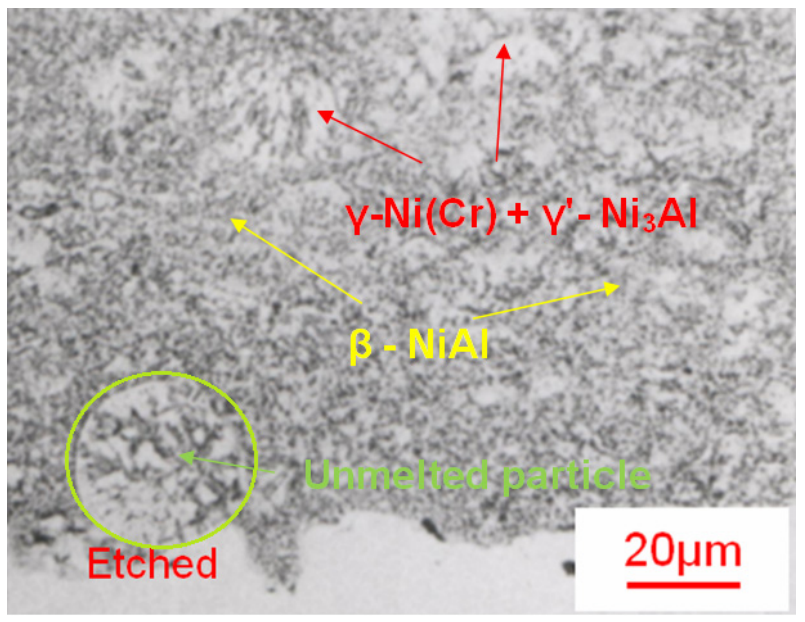

Figure 4-(OM) Etched microstructure of the vacuum plasma sprayed

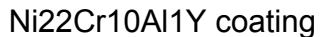

Puc. 4 - (ОМ) Поврежденная микроструктура покрытия, нанесенного вакуумным плазменным напылением Ni22Cr10A/1Y

Слика 4 - (ОМ) Нагризена микроструктура вакуум-плазма напрскане превлаке Ni22Cr10Al1Y

Light gray regions of the solid $\mathrm{Y}-\mathrm{Ni}(\mathrm{Cr})$ solution with $\mathrm{Y}^{\prime}-\mathrm{Ni3A}$ precipitates are clearly seen as well as the dark gray region of the $\beta-\mathrm{NiAl}$ phase. The substrate/coating interface shows one unmelted powder particle of $25 \mu \mathrm{m}$ which is fully united with the deposited coating layers. The presence of the unmelted particle did not affect the formation of pores in the coating around it.

After heat treating the coating in vacuum in order to strengthen the deposited layers by thermal precipitation of intermetallic $\mathrm{Y}^{\prime}-\mathrm{Ni}_{3} \mathrm{Al}$ compounds, the coating is more homogeneous with respect to the deposited state (Figure 5). Homogeneity is a consequence of the increased solubility of $\mathrm{Al}$ in the $\mathrm{y}$ phase at a temperature of $1100{ }^{\circ} \mathrm{C}$. During the heat treatment of $\mathrm{Al}$ and $\mathrm{Ti}, \mathrm{Y}^{\prime}$ intermetallic compounds $\mathrm{Ni}_{3}(\mathrm{Al}, \mathrm{Ti})$ are formed with $\mathrm{Ni}$ from the substrate, thus enhancing the coating and increasing its resistance to high temperature creep, together with the substrate. 


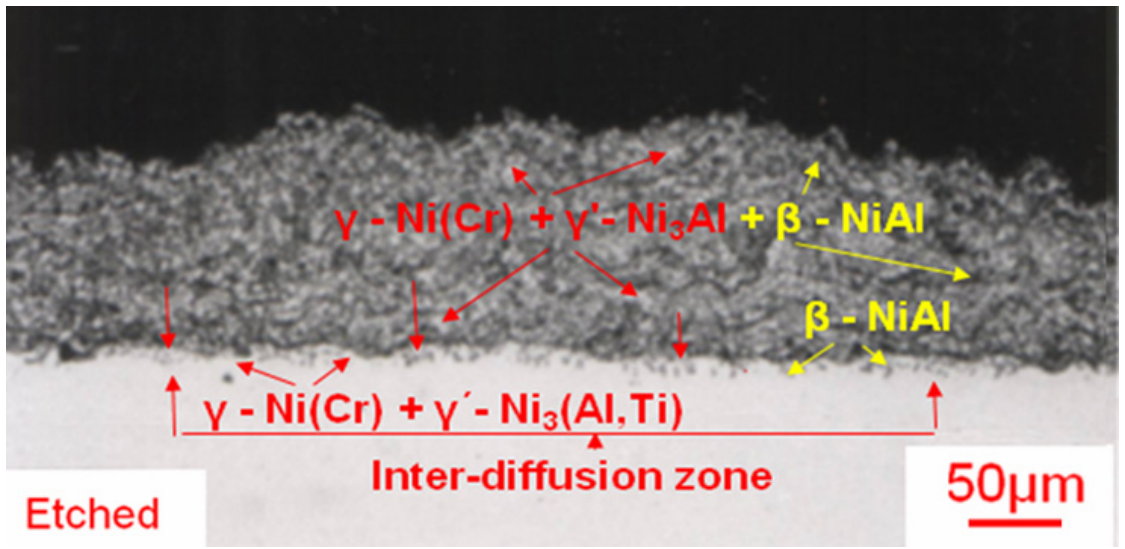

Figure 5 - (OM) Etched microstructure of the Ni22Cr10Al1Y coating after heat treatment at $1100^{\circ} \mathrm{C} / 2$ hours

Puc. 5 - (ОМ) Поврежденная микроструктура покрытия Ni22Cr10Al1Y после термической обработки при $1100^{\circ} \mathrm{C} / 2$ часа

Слика 5 - (ОМ) Нагризена микроструктура превлаке Ni22Cr10Al1Y после термичког третмана на $1100^{\circ} \mathrm{C} / 2$ сата

After heat treatment under vacuum at a temperature of $1100{ }^{\circ} \mathrm{C}$ for 2 hours, the microstructure of the Ni22Cr10Al1Y coating shows globular particles of the $\beta$-NiAl phase (dark gray), evenly distributed in the $\mathrm{Y}-\mathrm{Ni}(\mathrm{Cr})$ $+\mathrm{y}^{\prime}-\mathrm{Ni}_{3} \mathrm{Al}$ matrix (light gray) (Funk, et al, 2011, pp.2233-2241). It is clearly visible that an inter-diffusion zone is formed on the inter-surface. Because of the dominant diffusion of $\mathrm{Al}$ and $\mathrm{Cr}$ from the coating into the substrate, a zone enriched with the $\beta-(\mathrm{NiAl})$ phase was formed on the interface in the substrate. The diffusion layer was formed of the $\mathrm{NiCr}$ matrix (light gray) and the deposited $\beta$-NiAl compounds (black). Because of the diffusion of $\mathrm{Al}$ into the substrate, the Al content is reduced in the coating. Substantial precipitates of the $\beta-\mathrm{NiAl}$ phase are woven in the diffusion zone which is in the base of the INCONEL X-750 alloy. Also, Ti from the substrate diffuses into the lower layers of the coating where it participates with $\mathrm{Al}$ in the formation of intermetallic $\mathrm{y}^{\prime}-\mathrm{Ni}_{3}(\mathrm{Al}, \mathrm{Ti})$ compounds (Itoh, Tamura, 1999, pp.476-483), (Gómez-Acebo, et al, 2004, pp.pp.237-251). The thickness of the diffusion zone formed of the $\mathrm{y}-\mathrm{Ni}(\mathrm{Cr})$ solid solution with precipitates and the $\beta-(\mathrm{NiAl})$ phase on the coating / substrate interface is $20 \mu \mathrm{m}$. 


\section{Conclusion}

at atmospheric pressure and as such can successfully be applied in hot 
sections of turbojet engines to protect them against high-temperature oxidation and corrosion.

\section{References}

Achar, D.R.G., Munoz-Arroyo, R., Singheiser, L. and Quadakkers, W.J., 2004. Modelling of phase equilibria in MCrAlY coating systems. Surface and Coatings Technology, 187(2-3), pp. 272-283. Available at: http://dx.doi.org/10.1016/j.surfcoat.2004.02.018.

Dahl, K.V., Hald, J., Horsewell, A., 2006. Interdiffusion between Ni-based superalloy and MCrAlY coating. Defect and Diffusion Forum, 258-260, pp.73-78. Available at: http://dx.doi.org/10.4028/www.scientific.net/DDF.258-260.73.

Feuerstein, A., Knapp, J., Taylor, T., Ashary, A., Bolcavage, A., Hitchman, N., 2008. Technical and Economical Aspects of Current Thermal Barrier Coating Systems for Gas Turbine Engines by Thermal Spray and EBPVD: A Review. Journal of Thermal Spray Technology, 17(2), pp.199-213. Available at: http://dx.doi.org/10.1007/s11666-007-9148-y.

Funk, M., Ma, K., Eberl, C., Schoenung, J.M., Göken, M. and Hemer, K.J., 2011. High-Temperature Mechanical Behavior of End-of-Life Cryomilled NiCrAlY Bond Coat Materials. Metallurgical and materials transactions A, 42A, pp.22332241. Available at: http://dx.doi.org/10.1007/s11661-011-0659-2.

Gómez-Acebo, T., Navarcorena, B., Castro, F., 2004. Interdiffusion in multiphase, Al-Co-Cr-Ni-Ti diffusion couples. Journal of Phase Equilibria and Diffusion, 25(3), pp.237-251. Available at: http://dx.doi.org/10.1007/s11669-0040112-y.

Itoh, Y. and Tamura, M., 1999. Reaction Diffusion Behaviors for Interface Between Ni-Based Super Alloys and Vacuum Plasma Sprayed MCrAlY Coatings. Journal of Engineering for Gas Turbines and Power, 121, pp.476-483. Available at: http://dx.doi.org/10.1115/1.2818497.

Liu, Y.Z., Hu, X.B., Zheng, S.J., Zhu, Y.L., Wei, H., Ma, X.L., 2015. Microstructural evolution of the interface between NiCrAlY coating and superalloy during isothermal oxidation. Materials and Design 80, pp. 63-69. Available at: http://dx.doi.org/10.1016/j.matdes.2015.05.014.

Ma, K., Tang, F. and Schoenung, J.M., 2010. Investigation into the effects of $\mathrm{Fe}$ additions on the equilibrium phase compositions, phase fractions and phase stabilities in the Ni-Cr-Al system. Acta Materialia, 58(5), pp.1518-1529. Available at: http://dx.doi.org/10.1002/adem.201100171.

Material Product Data Sheet, 2012. Nickel Chromium Aluminum Yttrium (NiCrAlY) Thermal Spray Powders, Amdry 9624, DSMTS-0102.0, Sulzer Metco.

Mendis, B.G. and Hemker, K.J., 2008. Thermal stability of microstructural phases in commercial NiCoCrAlY bond coats, Scripta Materialia, 58(4), pp.255258. Available at: http://dx.doi.org/10.1016/j.scriptamat.2007.10.016. 
Mrdak, M., 2012. Study of the properties of plasma deposited layers of nickel-chrome-aluminum-yttrium coatings resistant to oxidation and hot corrosion. Vojnotehnički glasnik/Military Technical Courier, 60(2), pp.182-201. Available at: http://dx.doi.org/10.2298/vojtehg1202182M.

Mrdak, M., 2013. Characterization of vacuum plasma sprayed cobalt-nickelchromium-aluminum-yttrium coating. Vojnotehnički glasnik/Military Technical Courier, 61(4), pp.26-47. Available at: http://dx.doi.org/10.5937/vojtehg61-2495.

Mrdak, M., Rakin, M., Medjo, B., Bajić, N., 2015. Experimental Study of Insulating Properties and Behaviour of Thermal Barrier Coating Systems in Thermo Cyclic Conditions. Materials \& Design, 67, pp.337-343. Available at: http://dx.doi.org/10.1016/j.matdes.2014.11.029.

Mrdak, M., 2016. Study of the application of plasma sprayed coatings on the sections of the Astazou III B turbo - jet engine. Vojnotehnički glasnik/Military Technical Courier, 64(1), pp.1-25. Available at: http://dx.doi.org/10.5937/vojtehg64-8933.

Padture, N.P., Gell, M. and Jordan, E.H., 2002. Thermal barrier coatings for gas-turbine engine applications. Science, 296 (5566), pp.280-284. Available at: http://dx.doi.org/10.1126/science.1068609.

Tang, F., Ajdelsztajn, L., Kim, G.E., Provenzano, V. and Schoenung, J.M., 2006. Effects of variations in coating materials and process conditions on thethermal cycle properties of NiCrAlY/YSZ thermal barrier coatings. Materials Science and Engineering A, 425(1-2), pp.94-106. Available at: http://dx.doi.org/10.1016/j.msea.2006.03.043.

Turbojet Engine - Standard Practices Manual PN 582005, 2002. Pratt \& Whitney, East Hartford, USA.

Wang, B., Gong, J., Wang, A.Y., Sun, C., Huang, R.F. and Wen, L.S., 2002. Oxidation behavior of NiCrAlY coatings on Ni based superalloy. Surface and Coatings Technology, 149, p.70. Available at: Available at: http://dx.doi.org/10.1016/S0257-8972(01)01427-X.

Yuan, K., Eriksson, R., Lin Peng, R., Li, X., Johansson, S., Wang, Y., 2014. MCrAIY coating design based on oxidation - diffusion modelling. Part I: Microstructural evolution. Surface and Coatings Technology 254, pp.79-96. Available at: http://dx.doi.org/10.1016/j.surfcoat.2014.05.067.

\section{СТРУКТУРА И СВОЙСТВА ПОКРЫТИЯ Ni22Cr10AІ1Y НАНЕСЕННОГО МЕТОДОМ ВАКУУМНОГО ПЛАЗМЕННОГО НАПЫЛЕНИЯ}

\section{Михаило Р. Мрдак}

Центр исследований и развития А.О. «ИМТЕЛ коммуникации», г. Белград, Республика Сербия

ОБЛАСТЬ: химические технологии

ВИД СТАТЬИ: оригинальная научная статья ЯЗЫК СТАТЬИ: английский 
Резюме:

В данной статье описан процесс нанесения покрытия Ni22Cr10Al1Y вакуумным плазменным напылением для защиты деталей газотурбинного двигателя от оксидирования $u$ высокотемпературной коррозии. Покрытие может оказать значительное воздействие на свойства субстрата, так как вместе с ним создает композит.

Течение процесса депозиции покрытия и режим термической обработки с субстратом значительно влияют на стойкость слоев покрытия к высокотемпературной ползучести.

Нанесение порошка Ni22Cr10A/1Y произведено аппаратом вакуум плазменного напыления om производителя Plasma Technik - AG, включающим пульт управления A-2000 и плазматрон F4. Покрытие нанесено на субстрат сплава INCONEL X-750, затем произведена двухчасовая техническая обработка при $1100^{\circ} \mathrm{C}$ в защитной среде аргона. Морфология частиц порошка испытана методом оптической микроскопии. Анализ механических характеристик покрытия проведен на основании испытаний микротвердости методом $H_{0.3}$ u прочности соединений методом растяжения. Микротвердость покрытия соответствуют требованиям стандартов Pratt \& Whitney. Микроструктура слоев нанесенного покрытия испытана методом световой микроскопии. Повреждения покрытия вызваны раствором азотной кислоты $2.5 \mathrm{ml} \mathrm{HNO}_{3} \mathrm{C}$ $7.5 \mathrm{ml}$ плавиковой кислоты.

полализ микроструктуры повреждений покрытия до и толщины диффрузной части проведен методом световой микроскопии, на основании результатов анализа дана оценка качества покрытия.

Ключевые слова: вакуум, субстраты, структурные свойства, плазма, слои, покрытие.

СТРУКТУРА И СВОЈСТВА ПРЕВЛАКЕ Ni22Cr10AI1Y ДЕПОНОВАНЕ ВАКУУМ-ПЛАЗМА-СПРЕЈ ПРОЦЕСОМ

Михаило Р. Мрдак

Истраживачки и развојни центар ИМТЕЛ Комуникације а. д., Београд,

Република Србија

ОБЛАСТ: хемијске технологије

ВРСТА ЧЛАНКА: оригинални научни чланак

ЈЕЗИК ЧЛАНКА: енглескИ 
Сажетак:

Циљ рада јесте да се вакуум-плазма-спреј процесом депонују слојеви превлаке Ni22Cr10Al1Y за заштиту компоненти гасних турбина од оксидације и високотемпературне корозије. Превлака може знатно утицати на својства субстрата, јер заједно са субстратом формира композит. Врста процеса депозиције превлаке и режим термичке обраде превлаке са субстратом битно утичу на њену отпорност на високотемпературно пузање. Депоновање праха Ni22Cr10Al1Y урађено је вакуум-плазма-спреј системом фрирме Plasma Technik - AG који користи командни пулт A-2000 и плазма пиштољем F4. Превлака депонована на субстрату од легуре INCONEL X-750 термички је обрађена на $1100^{\circ} \mathrm{C}$ у трајању од 2 сата у заштитној атмосфрери аргона. Морфрологија честица праха испитана је методом скенине електронске микроскопије. Испитивања микротврдоће слојева рађена су методом $H V_{0.3}$ и чврстоће споја методом испитивања на затезање, која су била у складу са стандардом Pratt \& Whitney. Микроструктура слојева превлаке у депонованом стању испитана је на светлосном микроскопу. Нагризање превлаке рађено је мешањем азотне киселине 2,5 ml $\mathrm{HNO}_{3}$ ca $7,5 \mathrm{ml}$ фрлуороводоничне киселине HF. Анализа микроструктуре нагризене превлаке пре и после термичке обраде, као и дебљина дифузионе зоне, изведена је на светлосном микроскопу, на основу чега је оцењен квалитет превлаке.

Кључне речи: вакуум, субстрати, структурна својства, плазма, слојеви, превлаке.

Paper received on / Дата получения работы / Датум пријема чланка: 26. 09. 2016. Manuscript corrections submitted on / Дата получения исправленной версии работы / Датум достављања исправки рукописа: 05. 12. 2016.

Paper accepted for publishing on / Дата окончательного согласования работы / Датум коначног прихватања чланка за објављивање: 07. 12. 2016.

(C) 2017 The Author. Published by Vojnotehnički glasnik / Military Technical Courier (www.vtg.mod.gov.rs, втг.мо.упр.срб). This article is an open access article distributed under the terms and conditions of the Creative Commons Attribution license (http://creativecommons.org/licenses/by/3.0/rs/).

() 2017 Автор. Опубликовано в «Военно-технический вестник / Vojnotehnički glasnik / Military Technical Courier» (www.vtg.mod.gov.rs, втг.мо.упр.срб). Данная статья в открытом доступе и распространяется в соответствии с лицензией «Creative Commons» (http://creativecommons.org/licenses/by/3.0/rs/).

(c) 2017 Аутор. Објавио Војнотехнички гласник / Vojnotehnički glasnik / Military Technical Courier (www.vtg.mod.gov.rs, втг.мо.упр.срб). Ово је чланак отвореног приступа и дистрибуира се у складу са Creative Commons licencom (http://creativecommons.org/licenses/by/3.0/rs/).

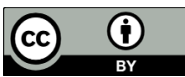

